\title{
»Oci jedoše kiselo grožđe, a sinovima zubi trnu « (Jer 31,29)
}

\author{
Etiološko čitanje starozavjetne pedagogije
}

Danijel Berkovic**

\begin{abstract}
Sažetak
Društveni procesi prepoznaju suštinsku razliku između pojmova temeljne i dominantne vrijednosti. Vrijednosti na kojima počiva sveukupni vrijednosni sustav neke zajednice smatraju se temeljnim i normativnim vrijednostima toga društva. Te temeljne vrijednosti katkad nisu i prevladavajuće (dominantne), što dovodi do neuskladenosti između temeljnih (deklariranih) $i$ dominantnih (prevladavajućih) vrijednosti. One koje dominiraju mogu čak biti i u suprotnosti s temeljnim vrijednostima.

Biblijski didaktički tekstovi mudrosnih tradicija (Knjiga o Jobu, Mudre izreke, Propovjednik) učestalo upućuju na neke odgojno-obrazovne temeljne vrijednosti izraelićanske zajednice. U tom roditelj, osobito otac, zauzima bitno mjesto. U stvarnosti se pak zamjećuje nesklad izmedu tih temeljnih vrijednosti i vrijednosti koje dominiraju. Naime, s jedne je strane imamo, »Sine moj, čuj moju mudrost « (Izr 5,1), »Polušaj, sine moj, pouku oca svoga « (Izr 1,8) i personificirana mudrost koja »odgaja sinove svoje" (Sir 4,11). S druge strane biblijski narativ upućuje na ovo poslovično: »Oci jedoše kiselo grožđe, a sinovima zubi trnu« (Jer 31,29). Znatan je broj biblijskih narativa u kojima nailazimo tragove gdje su sinovi predstavljeni kao slab rezultat otčinskih propusta. U ovom se radu ispituju i preispituju razlozi i uzroci koji dovode do takvoga nesklada izmedu temeljnih i prevladavajućih vrijednosti. Etiologija kao biblijski hermeneutski predložak, kojim se pojašnjavaju pravi uzroci pojedinih situacija, može biti jedno od pojašnjenja spomenute diskrepancije.
\end{abstract}

Ključne riječi: pedagogija; etiologija; hermeneutika; kiselo grožđe; fanatik; zamjensko majčinstvo

* Dr. sc. Danijel Berković, Biblijski institut. Adresa: Kušlanova 21, Zagreb, Hrvatska. ORCID iD: https://orcid.org/0000-0001-5287-3944. E-adresa:dberkovi@outlook.com 


\section{Uvod}

Starozavjetni narativ u mnogo epizoda ocrtava otčeve kao odgojitelje, s polovičnim ili vrlo upitnim uspjehom. Prispodoba o otčevima koji »jedoše kiselo grožđe«, a sinovima »zubi trnu « postaje već poslovični indikator stvarnoga stanja stvari. Biblijske otčinsko-odgojne pripovijesti ukazuju na dvije stvari. Prvo, u većini slučajeva odgojna uspješnost biblijskih otčeva pokazuje se vrlo upitnom. Uz ovdje navedene primjere, formalno ali i tekstualno, lako je provjerljivo i uočljivo kako nam biblijski tekst upravo nameće primjere otčinske odgojne neuspješnosti. Iako bi svaka generalizacija bila neprimjerena i neprikladna, zbroj epizoda u kojima biblijski otčevi griješe u svojoj edukativnoj ulozi daleko premašuje eventualne primjere uspješnosti. Ovdje smo se odlučili analizirati samo pet takvih autentičnih primjera interakcije na relaciji otac-sin, koji su indikativni i za mnoge druge biblijske epizode. ${ }^{1}$ Drugo, postavlja se pitanje jesu li takve pripovijesti zapravo u svojoj naravi i intenciji etiologija, gdje je pedagoška sastavnica zapravo u službi hermeneutskoga i teološkoga čitanja.

\section{Kiselo grožde}

Prispodoba o otcima koji su jeli kiselo grožđe upućuje na obiteljsku odgovornost otca i muškarca, koji je pater familias, ali je i pater educator. Što u cijeloj prispodobi ima značiti sintagma kiselo grožđe? Dvije se stvari odmah nameću. Prvo, tu je riječ o zelenom, dakle nedozrelom grožđu, a ne o kakvoj kiseloj sorti grožđa. Dakle, metafora bi se odnosila na "nezrele" odluke (ne)odgovornih otčeva. ${ }^{2}$ Tekst zapravo upućuje na to da su otčevi kao otčevi nezreli oni sami, koji su "jeli” takvo nedozrelo grožđe i donosili ne(do)zrele odluke. Drugo, očekivali bismo ako kiselo grožđe jedu otci, da će upravo njima koji jedu kiselo grožđe trnuti zubi. Zašto bi zubi imali "trnuti” onima koji toga grožđa nisu ni okusili? Čini se nelogičnim i nepravednim. Ili je i tu moguće u pitanju etiološko "učitavanje".

Izraz »oci jedoše kiselo grožđe, a sinovima zubi trnu « (Jer 31,29) u drevnom je Izraelu evidentno postala poslovična mudrost kojom se željelo razumjeti i pojasniti uzročno-posljedična veza u odgojno-obiteljskim životima ondašnjih ljudi. Prorok Ezekiel kaže: »Što vam je te o Izraelu ponavljate poslovicu [משל]:

1 Uz navedene primjere za koje smo se odlučili, među inima preostaju i ogledni primjeri: Noa, koji proklinje svojega sina Hama (Post 9); Samuel, koji svjestan korumpiranosti svoje sinove proglašava sudcima u Izraelu (1 Sam 8); Izak, koji favorizira sina Ezava, i ne samo stoga što je on njegov prvorođenac (Post 27). U svim tim primjerima umjesto roditeljskoga korektiva sinovima su dane povlastice.

2 Korisno je i zanimljivo pogledati u komentar oko "kiseloga grožđa" koji daje biblijski prevoditelj Silvije Grubišić u svojem prijevodu na Jer 31,29. On ispravno primjećuje da se בסר odnosi na nedozrelo, još zeleno grožđe, a ne na kiselu sortu grožđa (Grubišić i Raspudić, 2010, Jer 31,29, komentar u bilješci).

3 U radu s ciljem usporedbe na više mjesta donosimo hebrejski izvornik svetopisamskih tekstova, što je provedeno prema izdanju Biblia Hebraica Stuttgartensia (BHS, 1967-1977). 
jedoše kiselo grožđe, sinovima trnu zubi!' « (Ez 18,2). ${ }^{4}$ U primjeru djeluje nekoliko čimbenika oko kojih se valja potruditi jer omogućuju bolje razumijevanje poslovične biblijske mudrosti. Treba spomenuti barem tri.

Prvo, je li u pitanju samo pedagoško-odgojni aspekt starozavjetnih otčeva odgojitelja, ili se kroz te pedagoške biblijske tekstove provlači etiološko-hermeneutska nakana biblijskoga pisca i providnost božanske intervencije? Drugo, starozavjetna pedagogija odgojnu ulogu žene rijetko spominje, pa se čini da je u starozavjetnim obiteljsko-roditeljskim sferama pedagogije postojao "dvostruki lanac zapovijedanja” otčeva i majki. Biblijski tekstovi o tom bjelodano svjedoče primjerima majčinskih pedagoških intervencija, koje se ipak ne mogu svrstavati u odgojne mjere. Između ostalih majki, o tome svjedoče Sara (Post 16,4-6; 21,9-11) 5 i Rebeka (Post 27,5-13). ${ }^{6}$ Jedna velika starozavjetna majka, Bat Šeba, Davidova žena, intervenirala je kod muža za svojega sina Salomona kako bi on postao kraljem (1 Kr 1,11-35). Svi ti tekstovi nisu samo pedagoške naravi. Oni služe kao etiološko-hermeneutska čitanja tih pripovijesti i biblijske povijesti. Treće, i konačno, valja jasno odrediti na što se točno odnosi »kiselo grožđe« u izrazu »oci jedoše kiselo grožđe«.

\section{Etiologija, teologija i generacijsko prokletstvo}

Teološka je etiologija osebujna biblijsko-hermeneutska forma koja neko zatečeno stanje opisuje i tumači posljedično. Ona opisuje prošle događaje, ali u njima pravda i tumači zatečeno sadašnje stanje. Etiologija je hermeneutska intervencija u tekstu i retroprojekcija, kao svojevrsno čitanje "unatrag". 7

Eksplicitan primjer biblijske etiologije nalazimo u opisu gdje biblijski pisac ukazuje na odgovornost žene za istočni grijeh (Post 3), peccatum originale originans, čime se posljedično određuje buduća povijesna podređenost i odgovornost žene (usp. Berković, 2009). Začudno, biblijski pak tekst odgovornost za sveukupno stanje izričito svaljuje na prvoga čovjeka, muškarca Adama. Tekst i kontekst izrijekom govori: »čovjeku reče: 'Jer si poslušao glas svoje žene te jeo sa stabla s kojega sam ti zabranio jesti rekavši: S njega da nisi jeo! — evo: Zemlja neka je zbog tebe prokleta« (Post 3,17). Svojevrsnim etiološkim učitavanjem novozavjetni biblijski pisac, slijedeći etiološko zaključivanje, pokornički status žene

4 Grubišić je dosljedniji izvornomu tekstu kada prevodi: »kakvo je značenje poslovice, što je upotrebljavate u izraelskoj zemlji: 'Zobaše oci zeleno grožđe, stoga djeci trnu zubi?' " (Grubišić i Raspudić, 2010, Ez 18,2).

5 Abrahamova žena Sara intervenirala je kada je trebalo eliminirati Jišmaela iz obiteljskoga rodoslovlja, na što otac Abraham nije utjecao.

6 Rebeka je intervenirala za svojega sina Jakova, a na štetu svojega prvorođenca Ezava.

7 Termin etiologija dolazi od grč. $\alpha \iota \tau \iota \alpha$ ('uzrok, razlog') i $\lambda$ ó ${ }_{0} \varsigma$ ('riječ, znanost'), dakle “znanost o uzrocima”. U medicinskoj terminologiji, u užem smislu, zapravo je riječ o povijesti bolesti. U teološkom vokabularu etiologija se pak odnosi na uzroke nekoga zatečenoga stanja. Adalbert Rebić (2004) iscrpno je predstavio povijest etiologije kao hermeneutske metode u kontekstu biblijske teologije. 
potkrijepit će time što će od nje zahtijevati da bude tiha i mirna, pa ženi priliči da $\mathrm{u}$ »miru prima pouku sa svom podložnošću « $(1$ Tim 2,11$)$. Novozavjetni pisac zaključuje: »Adam nije zaveden, a žena je zavedena « (1 Tim 2,14), što pak nije nužno usklađeno s tekstom iz Post 3,17. Slijedeći etiološku logiku i formu, za ženu stvari postaju dodatno složenije. Novozavjetni pisac naime zalazi u područje soteriologije, pa neobično zaključuje da ženi spas dolazi »rađanjem djece« (1 Tim $2,15) .{ }^{8} \mathrm{~S}$ obzirom na to da starozavjetni tekstovi pretpostavljaju odgojnu odgovornost muškarca, je li moguće da etiologija, u ovom slučaju "igra" u korist muškarca?

\subsection{Etiologija i pedagogija}

U čemu je ovaj etiološki uvodnik relevantan za biblijsko-pedagoške tekstove? Kako su biblijska teološka etiologija i biblijska pedagogija povezani? Ako je teološka etiologija način tumačenja biblijskoga teksta, znači li to da je etiologija u povlaštenom položaju u odnosu na biblijsku pedagogiju? Bitno je zapravo pitanje: Je li starozavjetna biblijska pedagogija u službi etiološkoga čitanja nekoga biblijskoga teksta? Kao paradigmatski primjer etiološkoga čitanja, epizoda iz obitelji Abrahama i Sare (Post 16-18; 21) jasno ukazuju na tragove etiologije.

U rodoslovnoj pripovijesti (Post 16), moguće je da bi Jišmael, sin »po tijelu « $(\kappa \alpha \tau \alpha \sigma \alpha \rho \kappa \alpha)^{9}(\mathrm{Gal} 4,23)$ ipak mogao postati i sin prvenac (בכור). Sara je naime svojega muža Abrama nagovorila i uputila da legne s njezinom sluškinjom Hagarom: »Hajde k mojoj sluškinji, možda ću imati djece« (Post 16,2). ${ }^{10}$ Temeljem takvoga zamjenskoga majčinstva Sara bi postala majkom, a sin iz takve veze po automatizmu bi postao sin prvenac sa svim stečenim pravima (usp. Pnz 21,1517). ${ }^{11}$ Po zbroju tih dvaju tekstova (Post $16 ; 18$ ) etiološko čitanje nedvojbeno ukazuje na Izaka, koji ima po obećanju biti u prvenstvu. On time ujedno postaje metaforom za novi savez temeljen na vjeri i obećanju. Jišmael, kako to biblijski tekstovi naknadno pojašnjavaju, sin je »po tijelu« (tj. po zakonima tijela), ali ne i po obećanju. Spomenuti novozavjetni tekst tu starozavjetnu obiteljsku epizodu postavlja u službu teološke etiologije, pa bi se moglo zaključiti da pedagogija obitelji i braka u tom slučaju padaju u drugi plan. ${ }^{12}$

8 Susljedno tim etiološkim čitanjima, žena postaje "slabijim spolom" i po spoznajnim sposobnostima (usp. 1 Kor 14,35; 1 Pt 3,7). Kako takav soteriološki zaključak uravnotežiti u odnosu na neudanu ženu? Povijesno, nudi se rješenje koje zagovara i naglašava ženinu dužnost rađanja.

9 Citati grčkoga prijevoda Biblije doneseni su prema Novum Testamentum Graecum (NTG, 2014).

10 Skoro identičnu pripovijest o takvom, nazovimo to, zamjenskom majčinstvu nalazimo u još jednoj obiteljskoj priči i prijeporu između Jakova i Rahele, koja nije mogla rađati, pa je ponudila Jakovu istovjetno rješenje kao i Sara Abramu: neka Jakov legne s Bilhom (Rahelinom sluškinjom), te da potom Bilha rodi na Rahelinim koljenima, koja reče: »da tako i ja stečem djecu po njoj « (Post 30,3).

11 »Ako koji čovjek imadne dvije žene: jednu koja mu je draga, a drugu koja mu je mrska, te mu i draga i mrska rode sinove, ali prvorođenac bude od one koja mu je mrska, onda, kad dođe dan da podijeli svoju imovinu među svoje sinove, ne smije postupiti prema prvorođencu od drage na štetu sina od mrske, koji je prvenac« (Pnz 21,15-16).

12 Tu naravno valja voditi računa i o znatnim utjecajima dviju vodećih tradicijskih utjecaja — jahvističke i elohističke. 
Ostaju nam još otvoreni pedagoški primjeri odgojne odgovornosti otčeva koji »jedoše kiselo grožđe«, a sinovi (djeca) podnose ili snose posljedice otčinskoga odgojnoga neuspjeha. Stvari dodatno postaju složene kada se svemu pridoda faktor tradicijskih vjerovanja temeljenih na tekstovima u kojima je naznačeno kako grijesi roditelja kao posljedice prelaze na njihovu djecu, čime se ukazuje na svojevrsno generacijsko prokletstvo.

\subsection{Generacijsko prokletstvo}

Ako ovdje izraz »kiselo grožđe« razumijemo kao lanac (ne)odgovornosti biblijskih otčeva u odgajanju, umjesno je tada preispitati i pojam generacijskoga prokletstva. Generacijsko prokletstvo odnosi se na sve one nasljedne uzorke u obiteljskoj povijesti koji u sebi nose negativne trendove. U povijesti religije i tradicijskih vjerovanja patnja, trpljenje i bolest neposredno i nasljedno povezuju se $\mathrm{s}$ grijehom roditelja. ${ }^{13}$ Generacijsko prokletstvo $\mathrm{u}$ tom povezuje otčeve i sinove kao posljedično nasljedovanje otčinskih promašaja (usp. Ez 18,19-20). ${ }^{14}$

Novozavjetni tekstovi daju ilustrativne primjere tradicijskoga vjerovanja $\mathrm{u}$ generacijsko prokletstvo, kao u slučaju slijepca od rođenja kojega Isus iscjeljuje od njegove sljepoće (Iv 9,2). Nakon izlječenja slijepca, Isusovi učenici poželjeli su biti sigurni u slijepčevu anamnezu i povijest bolesti: »Učitelju, tko li sagriješi, on ili njegovi roditelji te se slijep rodio? « (Iv 9,2). Po izvještaju evanđelista Luke (Lk 13), skupina Galilejaca bila je nemilosrdno smaknuta u Jeruzalemu, i to pri liturgijskom obavljanju žrtvenih prinosa u hramu. Isusovi su učenici tomu odmah pridodali kaznu za neke njihove grijehe, pa ih Isus prijekorno upozorava: »Mislite li da ti Galilejci, jer tako postradaše, bijahu grešniji od drugih Galilejaca?« $(\mathrm{Lk} 13,2) .{ }^{15}$

13 Ugledni rabin amoraitskoga razdoblja Rabbi Ammi ovako sažimlje uzroke bolesti i smrti: »Nema smrti bez grijeha, ni patnje bez krivnje« (Shabbat Talmud). Rabin Ammi ben Nathan ugledni je rabin trećega amoraitskoga pokoljenja iz razdoblja od 250. do 290. godine. Amoraim ili amora ("oni koji govore narodu”) vrijeme je židovskih učenjaka i rabinskih naučitelja koje pokriva razdoblje od 200. do 500. godine.

14 U tom idolatrija, kao pošast, za biblijske Izraelce ima osobito mjesto, jer Jahve kažnjava idolatrijske grijehe otaca: »Jer ja, Jahve, Bog tvoj, Bog sam ljubomoran. Kažnjavam grijeh otaca - onih koji me mrze - na djeci do trećeg i četvrtog koljena, a iskazujem milosrđe tisućama koji me ljube i vrše moje zapovijedi« (Izl 20,5-6). Istovremeno, biblijski tekst ilustrira prilično drastične i represivne mjere koje roditelji poduzimaju na sina koji je "ništarija i pijanica" (וֹסֵָא זו ללל) (Pnz 21,20). Takav se ima za primjer drugima smaknuti, a roditelji ga imaju dovesti pred sugrađane, gdje će se javno izvršiti smrtna kazna: »Potom neka ga svi ljudi, njegovi sugrađani, kamenjem zasiplju dok ne pogine. Tako ćeš iskorijeniti zlo iz svoje sredine: sav će Izrael to čuti i bojat će se « (Pnz 21,21).

15 O povezanosti patnje i grijeha indikativan je i tekst iz Ivanova evanđelja u kojem Isus nakon izliječenja uzetoga upozorava: »Eto, ozdravio si! Više ne griješi da te što gore ne snađe!« (Iv 5,14). 


\section{Pozdrav fanaticima}

\subsection{Roditelj fanatik}

Fundamentalna je i nasušna potreba čovjeka kontinuitet postojanja. Instinkt produljenja vrste inherentno je svekolikomu živomu stvorenju. Nije stoga u pogibelji samo osobna borba za osobni opstanak. Život, kao takav, ne smije doći u terminalnu fazu, pa je riječ o "fanatičnom" instinktu održavanja i neprekinutosti kontinuiteta života, što je u religijsko-povijesnom smislu sržna poruka kršćanstva kao monoteističke vjere. ${ }^{16}$ U životinjskom svijetu svi se skrbe za svoju mladunčad, jer skrb za potomstvo u konačnici zapravo je skrb za održanje i nastavak života. Izrazi kao što su "fanatično" i "fanatizam" možda ne zvuče primamljivo, ali živopisno oslikavaju kontekst opstanka života. Pojmove valja pobliže pojasniti. Roditelja (otca) vjerojatno ne bismo olako klasificirali kao fanatika. Ipak pozornije valja promisliti i analizirati mogućnost da roditelj uistinu bude "fanatik" u smislu strastvene ushićenosti i nastojanja da odgoji svoje dijete kao produžetak vrste i samoga sebe. ${ }^{17}$

Izraelski pisac Amos Oz (1939.-2018.) u svojoj je posljednjoj knjizi Pozdrav fanaticima živopisno opisao i definirao fanatika: »fanatik se više zanima za tebe no za sebe sama. Želi spasiti tvoju dušu, želi te izbaviti, želi te osloboditi od grijeha, od pogreške, od pušenja, od tvoje vjere ili bezvjerja, želi poboljšati tvoje prehrambene navike, ili te izliječiti od ovisnosti o piću ili glasovanju. Fanatiku je jako stalo do tebe, uvijek ti se vješa oko vrata jer te iskreno ljubi, ili te hvata za grlo u slučaju da se pokažeš kao slučaj koji je neprijemčiv za izbavljenje. U svakom slučaju, s topografske točke gledišta, vješanje oko vrata i hvatanje za grlo gotovo su ista radnja $(\mathrm{Oz}, 2018,18)$.

Oz nastavlja da »fanatizam počinje u vlastitom domu« $(\mathrm{Oz}, 2018,43)$. To je roditelj fanatik koji svesrdno radi toliko da ti otvori oči, poduči, životno usmjeri, pa on ili ona postaju »altruističko stvorenje« $(\mathrm{Oz}, 2018,28)$. Čini se da su biblijski otčevi odista u tom smislu bili fanatici koji će učiniti sve za dobrobit djeteta. Katkad i pod cijenu da taj potomak bude razmaženi proizvod roditelja fanatika. O tom najbolje svjedoči niz obiteljskih epizoda iz biblijskih tekstova u kojima glavne uloge imaju otčevi odgajatelji svojih sinova, koji »jedoše kiselo grožđe«.

\subsection{Biblijski otčevi fanatici}

Za odgojnu metodu biblijski se otčevi nisu svojim sinovima »vješali oko vrata« ili ih »hvatali za grlo« $(\mathrm{Oz}, 2018)$, ali se je njihov slobodoumni pedagoški pristup

16 Ukupni obrazac kršćanstva i kršćanske vjere, u monoteističko-religijsko-povijesnom kontekstu, temelji se na pobjedi života nad smrti: »Gdje je, smrti, tvoja pobjeda?« (1 Kor 15,55). Dakako, prethodno kršćanstvu, judaizam je, kao osnova monoteizma, uveo pojam vječnosti (leolam) te izraze "u vijeke vjekova", "zanavijek", "život budućega vijeka" i sl. Jedan od najsažetijih iskaza o životu u kršćanskoj teologiji nalazimo u tekstu Prve Ivanove poslanice: »Život se očitova, i vidjeli smo i svjedočimo« (1 Iv 1,2). Pomalo filozofijski zagonetno, jer se pitamo, govori li pisac o osobi ili životu kao apstraktumu.

17 Lat. fanaticus (adj.), bjesneći, ushićen, oduševljen, strašan (Divković, 1900, s. v. fanaticus). 
pokazao kontraproduktivnim. Oni su svojim "ne-vješanjem" sinovima oko vrata omogućili da se dogode povijesno nerazmjerne posljedice za sav narod i zemlju. ${ }^{18}$

Eliju i Samuelu njihovi sinovi postali su izvorom korupcije, posredno i uzrokom propasti za Izrael. Za sinove velikoga svećenika Elija, Hofnija i Pinhasa kaže se da »nisu marili za Jahvu« (1 Sam 2,12). Biblijski ih pisac naziva ništari-

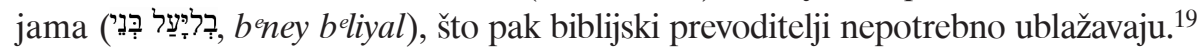
Samuelovi sinovi, Joel i Abija, »nisu išli stopama očevim« (1 Sam 8,3), što je u konačnici odredilo sudbinu cijeloga naroda, koji tada zahtijevao da im se imenuje kralj.

Jakovu je pak njegov sin Josip bio miljenik mimo svih ostalih sinova, pa mu je dao iskrojiti »kićenu haljinu« (Post 37,3), što je dodatno uzrokovalo zavist njegove braće te posredno dovelo do toga da su ga se njegova braća željela riješiti. ${ }^{20}$

Na te i još nekoliko primjera pobliže se usredotočujemo oko manjkavosti biblijskih otčeva odgojitelja. Također potvrđujemo pretpostavljenu teza da je u mnogim takvim tekstovima zapravo riječ o etiološkim pripovijestima i intervencijama Božje providnosti.

\section{Otčevi i sinovi}

\subsection{Abraham i sinovi (Post 16)}

Obiteljska pripovijest o Abrahamu i sinovima usredotočuje se na dva sina, Jišmaela i Izaka. Jišmael je po majci Hagari, Sarinoj sluškinji, svojevrsni primjer zamjenskoga majčinstva (Post 16,2). Izak je "legitimni" sin po majci Sari. Ti su sinovi paradigmatski likovi koji biblijskomu piscu služe u dihotomiji između dvaju zakona i zavjeta. Jedan (Jišmael) predstavlja prirodne zakone tijela. ${ }^{21}$ Drugi (Izak) je paradigmatski lik koji zastupa zakone Božjih obećanja i čovjekove vjere. ${ }^{22}$ Pripovijest o otcu Abramu i sinu Jišmaelu ima dvije varijante iz dviju predaja koje sagledavaju istu epizodu. U jahvističkom narativu (Post 16) Abram je dao ime svojemu sinu kojega je dobio sa Sarinom sluškinjom Hagarom: »Abram sinu

18 O tom svjedoče mnoge biblijske epizode otčeva i sinova, osobito one koje su kao u primjerima Elija, Hofnija i Pinhasa, Davida i Adonije te Solomona i Roboama zapravo vrlo ozbiljno naštetile tadašnjoj zajednici.

19 Biblijski prevoditelji tu nedovoljno odražavaju izvornik određujući Elijeve sinove kao nevaljale: »Elijevi sinovi bijahu nevaljali ljudi« (1 Sam 2,12); »Sinovi Elijevi bili su nevaljali« (Šarić, 2014, 1 Sam 2,12). Grubišić bez ublažavanja dobro prevodi beney belijal (בליעל בני) kao "ništarije": »Elijevi su sinovi, međutim, bili ništarije « (Grubišić i Raspudić, 2010, 1 Sam 2,12). Njihov odnos prema Gospodinu Sović prevodi: »nisu marili za Jahvu« (1 Sam 2,12), a Šarić: »Nisu marili ni za Gospodina " (Šarić, 2014, 1 Sam 2,12). Izvornik pak izrijekom kaže da "nisu poznavali Gospodina" (לאידאי (יהוה-את ידעו) (usp. Job 18,21). Možda bi taj odjeljak bilo bolje prevesti: "nisu se bojali Boga".

20 Pripovijest o Josipu i braći zapravo je klasični primjer biblijske etiologije gdje se Božjom providnošću rješavaju egzistencijalna pitanja cijeloga naroda, unatoč slabomu i potencijalno fatalnomu početku priče.

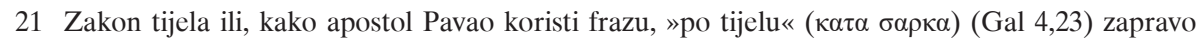
označava nešto što se odvija po uobičajenom i očekivanom razvoju događaja, gdje nije potrebna neka dodatna božanska intervencija, obećanje ili kakvo čudo. Jišmael je dakle rođen prirodnim načinima, a Izakovo je rođenje temeljeno Božjim obećanjem.

22 O tom zorno svjedoči tekst Pavlove poslanice Galaćanima (Gal 4,21-31). 
što mu ga rodi Hagara nadjene ime Jišmael« (Post 16,15). Elohistička varijanta ističe da se otac Abraham (više nije Abram!) usredotočuje na svojega sina od Sare, pa tekst kaže: »Abraham nadjene ime Izak svome sinu što mu ga Sara rodi« (Post 21,3). ${ }^{23}$ Prikaz te epizode zahtijeva pozorno čitanje jer se malo što može zaključiti iz odnosa otca Abrama i sina mu Jišmaela. Štoviše tu je više pozornosti dano Izaku, »sinu od slobodne«, sinu od obećanja, nego Jišmaelu, »sinu od sluškinje«, sinu »po tijelu « (Gal 4,21-31). Elohističko čitanje iste obiteljske epizode neosporno sadrži naglašene elemente etiologije. Indikativna je promjena imena Abrama u Abraham, gdje je naglašen element Božjega obećanja oko Sarina začeća. U konačnici imamo jednu pojedinost koja i nije detalj, a to je element cinizma u samom odabiru imena Izaka (יצחק) (Smješko?), slijedom Sarina podsmijeha (Post 18,12; 21,6), aludirajući na karakterističnu jahvističku opasku biblijskoga pisca: »Zar je Jahvi išta nemoguće? « (Post 18,14; usp. Post 21,3-6).

Abraham životnu pripovijest svojega sina Jišmaela prepušta svojoj ženi Sari (Post 16). Pomalo neobično, s obzirom na to da je riječ o izrazito patrijarhalnom društvu u kojem bi muškarčeva ipak trebala biti zadnja. ${ }^{24}$ Unatoč činjenici da je upravo njegova Sara predložila Abramu da legne i začne sina sa sluškinjom Hagarom, ona naknadno pomalo nesuvislo zaključuje: »Nepravda što se meni nanosi tvoja je krivnja!«(Post 16,5). Ali, nepravda je učinjena i Abrahamu. Sara je od Abrahama zatražila da Hagara i njegov sin Jišmael budu istjerani iz obiteljskoga doma, što je ozlovoljilo Abrama: »To je Abrahamu bilo nemilo, jer je i Jišmael bio njegov sin. Ali Bog reče Abrahamu: 'Nemoj se uznemirivati zbog dječaka i zbog svoje sluškinje; sve što ti kaže Sara poslušaj, jer će Izakovo potomstvo tebi ovjekovječiti ime. I od sina tvoje sluškinje podići ću velik narod, jer je tvoj potomak'« (Post 21,11-13).

Kontekstualiziramo li tu obiteljsku epizodu našim vremenima, zaključili bismo da je riječ o obitelji pred raspadom. Tu je ipak riječ o etiološkom čitanju teksta. ${ }^{25}$

\subsection{Moj naklon, sine (Post 37,10)}

U drevnom mitološkom simbolizmu, snovi, snoviđenja i astrološki znaci snivatelju ili tumaču snova dodavali su vrijednost njegove autoritativnosti. U takvim je situacijama od presudne važnosti bilo razumjeti i protumačiti takve sanje. Štoviše, snivatelju ili tumaču pridodavani su elementi nadnaravnoga autoriteta. Primjerice, Babilonski je kralj Nabukodonozor pomalo zabrinuto tražio da mu protumače njegov uznemirujući san: »neka mi pozovu sve mudrace babilonske da mi kažu što sanja znači« (Dn 4,3). Herod se je nervozno raspitivao kod »mudraca s Istoka« (Mt 2,2) koji su se nenadano pojavili u Jeruzalemu predvođeni pisno) nosi sudbu, osobno iskustvo nositelja imena, ali i svojevrsni usud imena mjesta.

24 »Tvoja je sluškinja u tvojoj ruci: kako ti se čini da je dobro, tako prema njoj postupi!« (Post 16,6).

25 O etiološkom čitanju svetopisamskih tekstova usp. Berković, 2009. 
vizijom zvijezde (snoviđenjem?) da mu pojasne pojavak toga tajanstvenoga novorođenoga djeteta. ${ }^{26}$

Josip je bio miljenik svojega otca Jakova, što je bilo uzrokom zavisti njegove braće i mržnje koja je iz toga proizišla: »zamrze ga toliko da mu nisu mogli ni prijaznu riječ progovoriti« (Post 37,4). Obiteljska se je situacija pogoršavala, što je došlo do krajnosti kada je Josip postao tajnoviti snivatelj vizija u kojima je sebe vidio kao onoga komu će se svi u obitelji početi klanjati (Post 37,7-9). ${ }^{27}$ Prednost koju je otac Jakov pružao sinu Josipu i prije je remetila stanje u obitelji. Pristranost i posebna sklonost otca jednomu sinu miljeniku dobro je poznata biblijska tema iz pripovijestima o Izaku i Ezavu (Post 25,28), o Jakovu i Benjaminu (Post 35,16-18), o razmetnom mlađem sinu (Lk 15), o Davidu i Adoniji (1 Kr 1), o Solomonu i Roboamu (1 Kr 11). Ti primjeri upućuju na "nezrele" odgojne prakse otčeva i o njihovim naklonostima, koji u konačnici, uz razmažene sinove, dovode i do nesagledivih posljedica po obitelj i narod. Josip je kao najmlađi od sinova otcu postao miljenik: »Izrael je volio Josipa više nego ijednog svoga sina jer je bio dijete njegove staračke dobi; i on mu napravi kićenu haljinu« (Post 37,3). Tom gestom otac je svojemu sinu miljeniku dodao privilegije, ali neizbježno oneraspoložio i razljutio ostalu braću. Čini se da se takve geste lako obiju o glavu i samomu roditelju. Otac Jakov ukorio je svojega miljenika Josipa nakon što je pretjerao sa svojim snoviđenjima, čime se je u obiteljskoj hijerarhiji uspinjao iznad svih ostalih. Nakon njegova drugoga sna otac ga je poveo u stranu: »Kad je to ispričao svome ocu, ukori [גער] ga otac i reče mu: 'Što znači taj san što si ga usnuo? Zar ćemo doći ja, tvoja majka i tvoja braća pa ti se do zemlje klanjati?' «(Post 37,10). ${ }^{28}$

Glagol גער u većini pojavaka u biblijskom tekstu naznačuje ukor u smislu 'ljutito izgrditi' ili 'slomiti'. ${ }^{29}$ Tu prijevod treba korigirati, uzimajući u obzir da tekst ovdje govori זרע (hebr. zara, 'sjeme'), dakle potomstvu. Potomstvu ce "trnuti zubi”, dakle ispaštati propuste (duhovnih) otčeva.

Josipova pripovijest nije samo pripovijest o odgojiteljskim promašajima, ona u sebi sadrži i etiološki element. Etiološki je element (tj. istraživanje stvarnih uzroka) tu zapravo providnost kojom Svevišnji planira spas svojega naroda u globalnoj krizi koja će tek uslijediti. Osim toga, teološki naglasak, karakterističan za jahvističku predaju, vrlo se snažno provlači kroz cijelu Knjigu postanka, gdje se stalno ističe Jahvina suverenost, koja (kod slabih, nemoćnih, životno ugroženih,

26 Cijeli je niz biblijskih tekstova u kojima snovi i snoviđenja upućuju bilo na neposrednu teofanijsku intervenciju ili pak jednostavno sujetu i taštinu snivatelja. U evanđelista Mateja, ilustrativan je primjer Pilatove žene, koja Pilata odvraća da se upliće u slučaj oko Isusa Nazarećanina: »Mani se ti onoga pravednika jer sam danas u snu mnogo pretrpjela zbog njega (Mt 27,19). Josipa su njegova braća zamrzila upravo zbog njegovih »pričanja o snovima« (Post 37,8).

27 Dva su sna koja je Josip podijelio sa svojom obitelji. U oba se on pojavljuje kao onaj koji je superioran svima njima. Prvi je san o snopovima žita i njemu kao povišenom snopu: »Uto se vaši snopovi okupe okolo i duboko se poklone mom snopu « (Post 37,7). U drugom snu Josip gleda zvijezde i zviježđa: »Pazite! Sunce, mjesec i jedanaest zvijezda duboko mi se klanjahu!« (Post 37,9).

28 "Pa će ti se do zemlje klanjati" - ארצה לך להשתחות.

29 Prorok Malahija opisuje ljutnju Jahve koji idolopokloničko svećenstvo opominje: »slomit ću vam ruku« (הזרע-את לכם גער הנני) (Mal 2,3; usp. Macintosh, 1969, 472). 
neplodnih majki) uvijek providnošću nadjačava i pobjeđuje. Takva je i Josipova pripovijest. Mladić je na rubu pogibije, preživi egipatsko sužanjstvo, ali postaje spasonosni izlaz za svu svoju obitelj.

\section{3. »Nije ih obuzdao« (1 Sam 3,13)}

Primjer velikoga svećenika Elija i njegovih sinova izvrstan je pokazatelj vjerske korupcije u svojem piramidalnom ustroju, s nesagledivim posljedicama. Od proroka Samuela Jahve je zatražio da Eliju objavi kraj njihovoj korupcijskoj praksi: »Ti ćeš mu objaviti da osuđujem kuću njegovu dovijeka; on je znao da njegovi sinovi hule na Boga, a nije ih obuzdao [כהה] «(1 Sam 3,13). ${ }^{30}$ Semantičko polje glagola עה ('obeshrabriti') ponešto je blisko glagolu עצב ('uzrokovati žal, ožalostiti'). Glagol כהה (kao u Iz 42,3) može imati i značenje 'ugasiti'. Isti glagol, ali u značenju 'oslabiti' (usp. Pnz 34,7) često se javlja u opisu slabljenja fizičke snage u staraca ili slabljenju vida (Post 27,1; Job 17,7). ${ }^{31}$

Svećenik Eli kao otac odgojitelj nije smogao snage da oslabi, obeshrabri ili ugasi zlodjela svojih sinova. Eli je, barem teoretski, posjedovao višestruki autoritet, kao otac, kao veliki svećenik i kao sudac u Izraelu. Odnos otca Elija prema svojim sinovima po mnogočemu nalikuje odnosu otca Davida prema svojem sinu Adoniji. Oba otca, iako su znala što im sinovi čine, nisu smogla snage stati tomu na kraj. Nezrela neodlučnost tih otčeva sasvim odgovara poslovičnoj mudrosti da su "jeli nezrelo grožđe”, a kazna i osuda ne padaju samo na sinove, nego na sav Elijev dom.

\section{4. »Nikad nije ukorio« $(1 \mathrm{Kr} 1,6)$}

Adonija, Davidov sin s Hagitom (2 Sam 3,4), jedan od pretendenata na otčevo kraljevsko prijestolje, postao je razmaženi mogući nasljednik bogatoga i uspješnoga otca kralja Davida. Ali taj ugledni kralj, "pastir naroda”, evidentno nije bio i uspješan odgojitelj svojemu sinu Adoniji, za koga je rečeno: »Njegov ga otac za svoga života nikad nije ukorio [אביו עצבו ולו] niti ga kad upitao: 'Zašto tako činiš?' Bio je, osim toga, stasit i lijep, a mati ga rodila poslije Abšaloma « $(1 \mathrm{Kr} 1,6) .{ }^{32}$

Sve upućuje na to da otac nije sina htio povrijediti ili ožalostiti ili izazvati upućujući ga na njegovo neispravno ponašanje. Čini se da je rezultat bio razmaženi sin, čiji su se prohtjevi uvijek uslišavali. U toj pripovijesti Davidov loš odgoj sina Adonije valja staviti i u kontekst Davidova vlastitoga djetinjstva i njegova obiteljskoga okružja. Je li David u djetinjstvu bio zanemaren, pa se je to poslije oslikalo i u njegovu odnosu prema svojemu sinu Adoniji? Iako u biblijskom tekstu nalazimo malo o odnosu otca Jišaja i njegova najmlađega sina Davida, daje se naslutiti Davidov položaj u otčevoj obitelji. U toj dobrostojećoj obitelji otac Jišaj imao je osam stasitih sinova (1 Sam 16,10) od kojih je osmi i najmlađi bio David (1 Sam

30 U Vulgati (1994) je prevedeno: »et non corripuit eos«.

31 »Mojsiju bijaše sto dvadeset godina kad umrije. Oko mu nije oslabilo niti mu je snaga popustila« (Pnz 34,7). »Ostarje Izak, vid mu se očinji gasio [כהה]« (Post 27,1).

32 Glagol עצב znači 'uzrokovati bol', 'ožalostiti'. 
16,11). ${ }^{33}$ Ispred tada iznimno utjecajnoga i uglednoga proroka, narodnoga vođe Samuela, Jišaj je pripravio mimohod svojih sedam od osam sinova, potencijalnih kandidata za novoga izraelskoga kralja. Biblijski tekst daje naslutiti da David, osim što je bio najmlađi, bio je i najnevažniji. Čini se da se oko obiteljskoga stola za Davida toliko i ne mari. Samuel zato ustrajava kod Jišaja kada kaže: »Pošalji po njega, jer nećemo sjedati za stol dok on ne dođe« (1 Sam 16,11). ${ }^{34}$

Potvrđuje se ipak da otac David svojim odgojnim nepostupanjem u odnosu na sina Adoniju zapravo donosi nezrele odluke, pa je i tu riječ o tom da je taj otac “jeo nezrelo grožđe”. U tekst je naime: »Njegov ga otac za svoga života nikad nije ukorio niti ga kad upitao: 'Zašto tako činiš?' Bio je, osim toga, stasit i lijep, a mati ga rodila poslije Abšaloma « (1 Kr 1,6). Za 'ukoriti' u izvorniku nalazimo עצב עצ' עצב ('slagol s prvotnim značenjem: 'suprotstaviti se'. Imenica od glagola ima značenje 'muka, trud, patnja' i javlja se samo nekoliko puta u Starom zavjetu. ${ }^{35}$ To može biti “put muke”, kao kada psalmist propitkuje: »pogledaj, ne idem li putem pogubnim [עצב דרך] i povedi me putem vječnim!« (Ps 139,24). ${ }^{36}$ Ali, trud (muka) može biti i dugoročni probitak, kako to veli pisac knjige Mudrih izreka: »U svakom trudu ima probitka« (Izr 14,23). ${ }^{37}$

Od nekoliko pojavaka deverbal (muka, trud) ima i jedno semantičko odstupanje, sa značenjem 'oblikovati, formirati' kao u: »Tvoje me ruke sazdaše, stvoriše, zašto da me sada opet raščiniš!« (ויעשוני עצבוני ידך) (Job 10,8).

Po svemu sudeći, otac David nije smogao snage (vremena?) da se u odgajanju u obiteljskom okruženju u potrebnom času suprotstavi Adoniji, da uloži trud i roditeljsku muku, kako bi se oblikovao karakter njegova sina Adonije. Zašto nam se ovo čini tako poznato? Adonija je mladić iz ugledne, bogate i utjecajne obitelji, k tomu šarmantan i zgodan, čini se i bez strogoga kućnoga odgoja — idealna je scenografija za nadolazeće probleme u obitelji. Zorno je prikazano bahato ponašanje Adonije, ali i razvoj događanja oko imenovanja Salomona, Adonijina brata, za kralja (1 Kr 1,5.15-27). U tome, intervencija Salomonove majke Bat-Šebe, kod kralja Davida, čini se još jednim primjerom etiološke nakane biblijskoga pisca.

33 »Tako Jišaj dovede sedam svojih sinova pred Samuela, ali Samuel reče Jišaju: ‘Jahve nije izabrao nijednoga od ovih.' Potom zapita Jišaja: 'Jesu li to svi tvoji sinovi?’ A on odgovori: 'Ostao je još najmlađi, on je na paši, za stadom.' Tada Samuel reče Jišaju: 'Pošalji po njega, jer nećemo sjedati za stol dok on ne dođe'" (1 Sam 16, 10-11).

34 Jasno je da Samuel u tom trenutku nije ni slutio kako bi upravo taj dječačić David mogao biti Božji izabranik. Pripovijest o otcu Jišaju i nevažnom sinu Davidu zapravo je klasična jahvistička priča o odabiru slaboga, neuglednoga.

35 Deverbal glagola עצב sa značenjem 'muka, trud, patnja' javlja se tek nekoliko puta u Starom zavjetu: Ps 139,24; Izr 10,22; Pro 14,23; 15,1; 1 Kr 1,6.

36 Neki עצב alternativno prevode kao idol: »See if an idol has held sway over me, and lead me into the eternal dominion « (Dahood, 1970, Ps 139,24). »Vidi, je li koji kumir imao vlast nada mnom; vodi me u vječnu Oblast svoju « (Grubišić i Raspudić, 2010, Ps 139,24). Logički i literarno-kontekstualno za takvo rješenje nema potrebe, štoviše Ps 139,24a i 139,24b u takvom rješenju zvuče nepovezano.

37 U tom kontekstu ne smijemo zanemariti prvi pojavak te imenice u biblijskom tekstu koji se odnosi na rađanje uz trud i muku: »Trudnoći tvojoj muke ću umnožit', u mukama djecu ćeš rađati« (Post 3,16$)$, što je zapravo etiološko čitanje toga teksta. 


\section{5. »Ne htjede žalostiti svoga sina Amnona«(2 Sam 13,21)}

Pripovijest o Amnonovu silovanju sestre Tamare zorno prikazuje prispodobu o “kiselu grožđu koje jedu otci”. Riječ je o dalekosežnim posljedicama po cijelu obitelj kralja Davida. "Trnuli su tada zubi” ne samo Davidovu sinu Abšalomu i bratu mu Amnonu, nego cijeloj obitelji. Nakon nesmiljenoga incidenta u kojem je brat silovao svoju sestru (2 Sam 13,10-12) — otac nije poduzeo ništa. ${ }^{38}$ Nakon što otac David dočuje o tom činu svojega sina Amnona, biblijski tekst govori: »Kad je kralj David čuo sve što se dogodilo, vrlo se razgnjevi, ali ne htjede žalostiti svoga sina Amnona, koga je ljubio jer mu bijaše prvorođenac« (2 Sam 13,21; usp. Keil i Delitzsch, 1984, 401).

Oko postupanja i reakcije kralja Davida na incident svojega sina Amnona, Septuaginta ovdje dodaje rečenicu: »ne htjede žalostiti svoga sina Amnona, koga je lju-

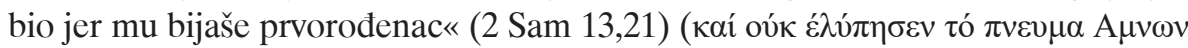

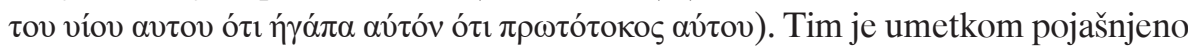
zašto Amnon nije bio kažnjen u skladu sa Zakonom, koji nalaže da se incest kažnjava smrću kako se nalaže u Levitskom zakonu: »Čovjek koji bi se oženio svojom sestrom, kćerju svoga oca ili kćerju svoje majke te vidio njezinu golotinju, a ona vidjela njegovu — pogrdno je to djelo! — neka se istrijebe pred očima naroda. Otkrio je golotinju svoje sestre, pa neka snosi i posljedice svoje krivnje« (Lev 20,17).

Reakciju kralja Davida, koja se je ipak svela samo na ljutnju (»vrlo se razgnjevi«) prema sinu Amnonu, a ne i na način ozbiljnijih sankcija u skladu sa Zakonom, moguće je protumačiti činjenicom vlastite krivnje u slučaju njegova preljuba s Bat Šebom, k tomu i ubojstva njezina muža. Davidov drugi sin Abšalom s bratom Amnonom prekinuo je svaku daljnju komunikaciju i kontakt (2 Sam 13,22). Sve to iznova potvrđuje ono proverbijalno gdje otčevi "jedu nedozrelo grožđe”, pa sukladno tomu donose i nedozrele odluke u svojoj odgajateljskoj ulozi.

\section{6. »Izrode i propalico!« (1 Sam 20,30)}

Slijedi teška epizoda i tužna scena između otca i sina. Rijetko, ako igdje u svetopisamskom tekstu nalazimo takvu razjarenost otca prema sinu, čak uz pokušaj ubojstva i proklinjanje. U više tekstualnih izvještaja Šaul je prikazivan kao čovjek brzoplete naravi. Kao narodni vođa lako plane bijesom (1 Sam 11). U strahu, čini se i u svojoj nesigurnosti, donosi krive odluke (1 Sam 13). U svojim postupanjima brani neobranjivo (1 Sam 15,9.20-21). ${ }^{39}$ Takvim temperamentom Šaul je izgubio i najbližega suradnika Davida, a u epizodi koju tumačimo i vlastitoga sina Jonatana.

38 »Tada Amnon reče Tamari: 'Donesi mi jelo u spavaonicu da se okrijepim iz tvoje ruke!' I Tamara uze kolače koje bijaše zgotovila i donese ih svome bratu Amnonu u spavaonicu. A kad mu je pružila da jede, on je uhvati rukom i reče joj: 'Dođi, sestro moja, lezi sa mnom!' «(2 Sam 13,10).

39 Primjer pobjede nad Amalečanima ne samo da je Šaulovo grubo kršenje Božje zapovijedi o izvršenju herema (kleto uništenje) (1 Sam 15,7-9), nego predstavlja pravdanje postupka koji ne može biti opravdan. Ono što je bilo dio "kletoga" zatora nikako ne može ujedno poslužiti i kao žrtva bogu Jahvi. Makar se je Šaul pred Samuelom pokušao pravdati riječima: »Ali je narod od plijena uzeo ovaca i goveda, i to najbolje na čemu se imao izvršiti 'herem', da žrtvuje Jahvi, tvome Bogu, u Gilgalu« (1 Sam 15,21). 
Čini se da je u incidentnim situacijama izvrijeđao i svoju ženu, što se iz biblijskoga teksta jasno dade naslutiti. U ovoj se je epizodi raskinula veza otca i sina (1 Sam 20). Prvo otac u jarosti pokušava ubiti svojega sina: »Šaul odape koplje na sina da ga probode« (1 Sam 20,33). Ponižava ga i vrijeđa teškim riječima: »Izrode i propalico! « (1 Sam 20,30). »Tada Šaul planu gnjevom na Jonatana i reče mu: 'Izrode [עוה] i propalico [מרדות]! Misliš da ne znam da si u savezu s Jišajevim sinom, na sramotu svoju i na sramotu majčinu krilu! «(1 Sam 20,30). »Jonatan ustade od stola sav jarostan i nije jeo ništa toga drugog dana u mjesecu jer se zabrinuo za Davida što ga je njegov otac pogrdio [הכלמו] (1 Sam 20,34). ${ }^{40}$ Sina je osramotio (כלם), a iz teksta se dade zaključiti da je otčev gnjev osim na sina ujedno bio uperen i na vrijeđanje vlastite supruge. Jonatana je nazvao izrodom (נעות בן) tj. 'sin izopačene žene' (1 Sam 20,30). Šaul je bio odlučan da se pod svaku cijenu, pa i sukobom sa svojom obitelji, riješi Davida. Bio je naravno potaknut zavišću prema Davidu, ali i osobnom otčinskom slabosti. On je zapravo sumnjao da su njegov vlastiti sin Jonatan i suparnik David u dogovoru, što je smatrao izdajom.

\section{Zaključak}

U radu se preispituju odgojni uspjesi ili neuspjesi starozavjetnih otčeva. Obzirom na evidentne odgojne neuspjehe ovih biblijskih otčeva, postavlja se pitanje koliko su to rezultati pedagoških (ne)uspjeha ili se ipak radi i o teološkim konstruktima, na tragu biblijske etiologije. Ovdje etiologija, kao biblijska književna forma, hermeneutski interpretira i naknadno tumači ove pedagoške uspjehe ili neuspjehe. Etiologija neko zatečeno stanje opisuje i tumači posljedično. Ona opisuje prošle događaje, ali u njima pravda i tumači zatečeno sadašnje stanje. Ona je zapravo retroprojekcija i čitanje 'unatrag' ali i teološka nakana biblijskog pisca.

Ovdje, u slučaju otčeva i sinova, slobodoumni pedagoški pristup otčeva umnogome pokazao se na prvi pogled kontraproduktivnim. No, etiološkim čitanjima ovih epizoda, primjetno je da će mnogi od ovih sinova (Izak, Jakov, Josip, David) postati instrumentima Božje providnosti. Mnogi od ovih otčeva svojim ne(do)zrelim pedagoškim postupcima zapravo su 'jeli kiselo grožđe' ali su se unatoč tome, ili baš zbog toga, otvarala vrata Božjoj providnosti. Kroz analizirane tekstove, evidentan je i utjecaj jahvističkog pisca koji ovdje koristi starozavjetnu pedagogiju za 'više ciljeve'.

\section{Literatura}

Berković, Danijel (2009). Od mizoginije do kulta: Etiološko čitanje Postanka 3. Kairos, 3(2), 50-66.

BHS (1967-1977). Biblia Hebraica Stuttgartensia. Stuttgart: Deutsche Bibelgesellschaft.

Biblija. Sveto pismo Staroga i Novoga zavjeta. Prevoditelji: Silvije Grubišić (Petoknjižje), Filbert Grass (Psalmi), Nikola Miličević (Pjesma nad pjesmama), Antun Sović (ostali dijelovi Staroga zavjeta), Bonaventura Duda i Jerko Fućak (Novi zavjet). Imprimatur: Hrvatska biskupska konferencija, 10. listopada 2008. Zagreb: Kršćanska sadašnjost, 2015.

40 Korijen glagola כלם ima značenje 'biti ponižen, osramoćen'. Ovdje (הכלמו) je u Hifilu, a u Jer 3 (הכלם) u Nifalu: »Čelo ti je kao u bludnice: ni zacrvenjela se nisi« (Jer 3,3). U epizodi Šaula i Davida, Hifil označava uzrok (poniženja) od strane Šaula prema Davidu. 
Dahood, Mitchell (1970). Psalms III: 101-150. New York: Doubleday.

Divković, Mirko (1900). Latinsko-hrvatski rječnik za škole. Zagreb. Kr. zemaljska tiskara.

Grubišić, Silvije; Raspudić, Gracijan (2010). Franjevačka Biblija. Stari zavjet preveo i popratio razjašnjenjima Silvije Grubišić, franjevac. Novi zavjet preveo i popratio razjašnjenjima Gracijan Raspudić, franjevac. Imprimatur: Biskupska konferencija BiH, 2009. Zagreb: Kršćanska sadašnjost.

Keil, Karl Fredreich; Delitzsch, Franz (1984). Commentary on the Old Testament in Ten Volumes: Vol. 2 (Joshua, Judges, Ruth, I\&II Samuel). Eerdmans Publishing Company.

Macintosh, Andrew A. (1969). A Consideration of Hebrew גער. Vetus Testamentum, 19(4), 471-479.

NTG (2014). Novum Testamentum Graecum. Stuttgart: Deutsche Bibelgesellschaft.

Oz, Amos (2018). Pozdrav fanaticima: Tri misli. Zagreb: Fraktura.

Rebić, Adalbert (2004). Etiologija kao biblijski način tumačenja početaka. U: Ivan Šporčić (ur.), Stari zavjet vrelo vjere i kulture (str. 10-26). Rijeka: Teologija u Rijeci.

Šarić, Ivan Evanđelist (2014). Biblija: Sveto pismo Staroga i Novoga zavjeta. Preveo Ivan Ev. Šarić. 8. popravljeno izdanje. Imprimatur: Biskupska konferencija BiH, 31. siječnja 2006. Sarajevo: Vrhbosanska nadbiskupija.

Vulgata (1994). Biblia Sacra Iuxta Vulgatam Versionem. Stuttgart: Deutsche Bibelgesellschaft.

»The fathers have eaten sour grapes, and the children's teeth are set on edge" (Jer 31,29)

An Etiological Reading of the Old Testament Pedagogy

Danijel Berković*

\section{Summary}

One of the key questions affirmed in this work was to what extent was the Old testament pedagogy in service of theological aetiology (etiology). After the examination of a selection of biblical texts and family stories, we can conclude that the Old testament pedagogy like a hair plait is fold with etiology. At the first glance biblical family stories seem to be primarily involved with the upbringing, only in the second 'layer' we notice etiological intent of the biblical writer. Hence, a majority of pedagogical biblical texts are, one way or the other, in service to aetiological and hermenutical ends. What does this really mean? With etiology, a specific biblical literary and hermenutical form, a biblical writer regularly demonstrate a theological intent by covertly implementing it into a story. Among several biblical family stories presented here, with fathers in their upbringing position, one of the most representative example of pedagogy-etiology is the episode in the lives of Sara and Abram and their sons Ishamael and Isaac. At the surface level, the story is a story of family complications, but at a deeper level it proves to be predominantly an etiological story. Clearly, biblical writer here uses this family story to announce, in paradigmatic form, the two laws. The law of nature and flesh (Ishmael) and the law of the spirit, promise and faith (Isaac). This becomes evident in the New testament text of the Pauline Epistle to Galatians.

Key words: pedagogy; etiology; hermeneutics; grapes; fanatic; surrogacy

* Danijel Berković, Ph.D., Biblical Institute. Address: Kušlanova 21, Zagreb, Croatia.

E-mail:dberkovi@outlook.com 